Argonne

\title{
Summary of Operations and Performance of the Utica Aquifer and North Lake Basin Wetlands Restoration Project in December 2009-November 2010
}

Environmental Science Division 
About Argonne National Laboratory

Argonne is a U.S. Department of Energy laboratory managed by UChicago Argonne, LLC under contract DE-AC02-06CH11357. The Laboratory's main facility is outside Chicago, at 9700 South Cass Avenue, Argonne, Illinois 60439. For information about Argonne and its pioneering science and technology programs, see www.anl.gov.

\section{Availability of This Report}

This report is available, at no cost, at http://www.osti.gov/bridge. It is also available on paper to the U.S. Department of Energy and its contractors, for a processing fee, from:

U.S. Department of Energy

Office of Scientific and Technical Information

P.O. Box 62

Oak Ridge, TN 37831-0062

phone (865) 576-8401

fax (865) 576-5728

reports@adonis.osti.gov

\section{Disclaimer}

This report was prepared as an account of work sponsored by an agency of the United States Government. Reference herein to any specific commercial product, process, or service by trade name, trademark, manufacturer, or otherwise, does not necessarily constitute or imply its endorsement, recommendation, or favoring by the United States Government or any agency thereof. The views and opinions of document authors expressed herein do not necessarily state or reflect those of the United States Government or any agency thereof, Argonne National Laboratory, or UChicago Argonne, LLC. 


\section{Summary of Operations and Performance of the Utica Aquifer and North Lake Basin Wetlands Restoration Project in December 2009-November 2010}

by

Applied Geosciences and Environmental Management Section Environmental Science Division, Argonne National Laboratory

February 2011 


\section{Contents}

Notation.

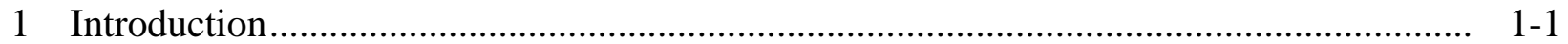

2 Overview of the Aquifer Restoration Facilities at Utica ........................................... 2-1

2.1 Wells GWEX1-GWEX3 and the Spray Irrigation Treatment Units........................ 2-1

2.2 Well GWEX4 and the Conventional Air Stripper .................................................. 2-1

2.3 Monitoring Well Network..................................................................................... 2-2

3 Overview of System Operations …..................................................................... $3-1$

3.1 Operation of Wells GWEX1-GWEX3 and the Spray Irrigation Treatment Units .... 3-1

3.2 Operation of Well GWEX4 and the Conventional Air Stripper ............................. 3-2

4 Groundwater Production Results ........................................................................ 4-1

4.1 Production by Wells GWEX1-GWEX3 ........................................................ 4-1

4.2 Production by Well GWEX4 …..................................................................... $4-2$

5 Groundwater Treatment Results ....................................................................... $5-1$

5.1 Results for Wells GWEX1-GWEX3, with Treatment by Spray Irrigation .............. 5-2

5.2 Results for Well GWEX4, with Treatment by Air Stripping.................................... 5-4

5.3 Estimated Removal of Carbon Tetrachloride from the Utica Aquifer....................... 5-4

5.4 Sampling of Monitoring Wells and Apparent Carbon Tetrachloride Concentration Trends in the Utica Groundwater ................................................. $5-5$

5.5 Evaluation of Groundwater Inorganic Geochemistry ........................................

6 Operation, Maintenance, and System Modifications ............................................... 6-1

6.1 Wells GWEX1-GWEX3 and the Spray Irrigation Treatment Units....................... 6-1

6.2 Well GWEX4 and the Air Stripping Unit........................................................ $6-1$

6.3 Operating and Maintenance Costs ................................................................... $6-2$

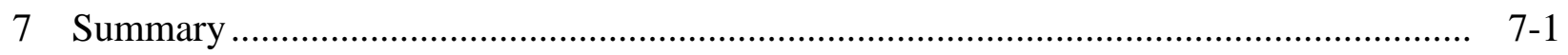

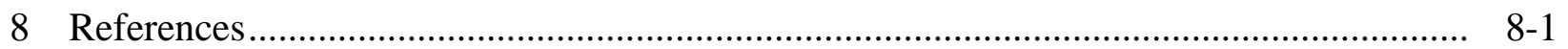




\section{Figures}

2.1 Locations of the restoration facilities, contaminant plume, and permanent monitoring wells at Utica

2.2 Spray irrigation unit in operation at Utica

5.1 Carbon tetrachloride concentrations at monitoring wells MW1-MW4, Sptember 2005 to November 2010

5.2 Carbon tetrachloride concentrations at extraction well GWEX1, November 2004 to November 2010.

5.3 Carbon tetrachloride concentrations at extraction well GWEX2, November 2004 to November 2010.

5.4 Carbon tetrachloride concentrations at extraction well GWEX3, November 2004 to November 2010 ...

5.5 Carbon tetrachloride concentrations at extraction well GWEX4, November 2004 to November 2010.

\section{Tables}

2.1 Summary of Construction Details for GWEX Wells at Utica ................................. 2-3

4.1 GWEX operation and groundwater production data in December 2009November 2010.

4.2 Comparison of actual well production rates and target rates

5.1 Analytical results for carbon tetrachloride in untreated groundwater samples and treated effluent samples in December 2009-November 2010.

5.2 Values for $\mathrm{pH}$ in untreated groundwater samples and treated effluent samples in December 2009-November 2010

5.3 Estimation of carbon tetrachloride removed from the Utica aquifer in December 2009-November 2010

5.4 Well construction data and analytical results for carbon tetrachloride in groundwater samples from the permanant monitoring wells 
Utica Annual Review, December 2009-November 2010

Version 00, 02/14/11

\section{Tables (cont.)}

5.5 Comparison of inorganic geochemical results for untreated groundwater samples and treated effluent samples........................................................................... 5-11

6.1 Summary of operating and maintenance costs for the Utica restoration project ........... 6-4

7.1 Summary of performance of the groundwater restoration systems at Utica.................. 7-4

7.2 Results of the groundwater extraction and treatment efforts at Utica, November 2004 to November 2010. 


\section{Notation}

$\begin{array}{ll}\text { BGL } & \text { below ground level } \\ \text { CCC } & \text { Commodity Credit Corporation } \\ { }^{\circ} \mathrm{F} & \text { degree(s) Fahrenheit } \\ \mathrm{ft} & \text { foot (feet) } \\ \text { gal } & \text { gallon(s) } \\ \text { gpm } & \text { gallon(s) per minute } \\ \text { GWEX } & \text { groundwater extraction } \\ \text { hr } & \text { hour(s) } \\ \text { in. } & \text { inch(es) } \\ \text { kg } & \text { kilogram(s) } \\ \text { L } & \text { liter(s) } \\ \mu \text { g/L } & \text { microgram(s) per liter } \\ \text { mg/L } & \text { milligram(s) per liter } \\ \text { MCL } & \text { maximum contaminant level } \\ \text { MW } & \text { monitoring well } \\ \text { NDEQ } & \text { Nebraska Department of Environmental Quality } \\ \text { NGPC } & \text { Nebraska Game and Parks Commission } \\ \text { NPDES } & \text { National Pollutant Discharge Elimination System } \\ \text { USDA } & \text { U.S. Department of Agriculture } \\ \text { VOC } & \text { volatile organic compound } \\ \text { yr } & \text { year(s) }\end{array}$




\section{Summary of Operations and Performance of the Utica Aquifer and North Lake Basin Wetlands Restoration Project in December 2009-November 2010}

\section{Introduction}

This document summarizes the performance of the groundwater restoration systems installed by the Commodity Credit Corporation of the U.S. Department of Agriculture (CCC/USDA) at the former CCC/USDA grain storage facility in Utica, Nebraska, during the sixth year of system operation, from December 1, 2009, until November 30, 2010.

In the project at Utica, the CCC/USDA is cooperating with multiple state and federal agencies to remove carbon tetrachloride contamination from a shallow aquifer underlying the town and to provide supplemental treated groundwater for use in the restoration of a nearby wetlands area. Argonne National Laboratory has assisted the CCC/USDA by providing technical oversight for the aquifer restoration effort and facilities during this review period.

This document presents overviews of the aquifer restoration facilities (Section 2) and system operations (Section 3), then describes groundwater production results (Section 4), groundwater treatment results (Section 5), and associated groundwater monitoring, system modifications, and costs during the review period (Section 6). Section 7 summarizes the present year of operation. Performance prior to December 1, 2009, has been reviewed previously (Argonne 2005, 2006, 2008, 2009a, 2010). 


\section{Overview of the Aquifer Restoration Facilities at Utica}

The principal components of the groundwater restoration systems at Utica are shown in Figure 2.1. The facilities consist of two main operating units, as described below. The facilities include four groundwater extraction (GWEX) wells. Table 2.1 summarizes construction details for these wells.

\subsection{Wells GWEX1-GWEX3 and the Spray Irrigation Treatment Units}

Extraction wells GWEX1-GWEX3, located in the northern portion of the town, are used to extract contaminated groundwater from the upgradient portion of the contaminant plume. These wells are linked by a distribution system that selectively carries untreated groundwater to either of two discharge points in the northern and southern subbasins of the North Lake Basin Wildlife Management Area (Figure 2.1). At each discharge point, the water is treated to remove carbon tetrachloride by using a custom spray irrigation treatment unit (Figure 2.2). The three extraction wells are operated simultaneously to maintain a critical operating pressure at each treatment unit.

Wells GWEX1-GWEX3 are operated intermittently during the year, subject to local weather conditions and in consultation with the Nebraska Game and Parks Commission (NGPC). The NGPC owns most of the property occupied by the wetlands and has administrative and technical responsibility for management of the wildlife area.

\subsection{Well GWEX4 and the Conventional Air Stripper}

Extraction well GWEX4 is located near the downgradient toe of the carbon tetrachloride plume (Figure 2.1) and is operated continuously as a containment well. Groundwater produced from GWEX4 is treated by using a conventional (shallow-tray) air stripping technique, and the effluent is discharged to the surface for reinfiltration into the shallow Utica aquifer. 


\subsection{Monitoring Well Network}

A network of seven permanent monitoring points has been established at Utica (Figure 2.1). Wells SB48, SB71, and SB72 were constructed during the early phases of the investigations at Utica. These wells were intended primarily for the measurement of groundwater levels; they do not penetrate the more contaminated zones of the groundwater column identified in detailed vertical-profile sampling (Argonne 2000, 2003). To improve monitoring coverage, additional wells MW1-MW4 were installed at strategic locations along the plume migration pathway in August 2005. 
TABLE 2.1 Summary of Construction Details for GWEX Wells at Utica.

\begin{tabular}{|c|c|c|c|c|}
\hline \multirow[b]{2}{*}{ Well } & \multicolumn{3}{|c|}{ Depth (ft BGL) } & \multirow[b]{2}{*}{$\begin{array}{c}\text { Casing } \\
\text { Diameter } \\
\text { (in.) }\end{array}$} \\
\hline & $\begin{array}{l}\text { Total } \\
\text { Depth }\end{array}$ & $\begin{array}{l}\text { Screen } \\
\text { Interval }\end{array}$ & $\begin{array}{c}\text { Gravel } \\
\text { Pack } \\
\text { Interval }\end{array}$ & \\
\hline GWEX1 & 132 & $106-126$ & $97-132$ & 8 \\
\hline GWEX2 & 148 & $110-145$ & $106-148$ & 8 \\
\hline GWEX3 & 146 & 105-140 & $101-146$ & 8 \\
\hline GWEX4 & 150 & 115-145 & 110-150 & 6 \\
\hline
\end{tabular}




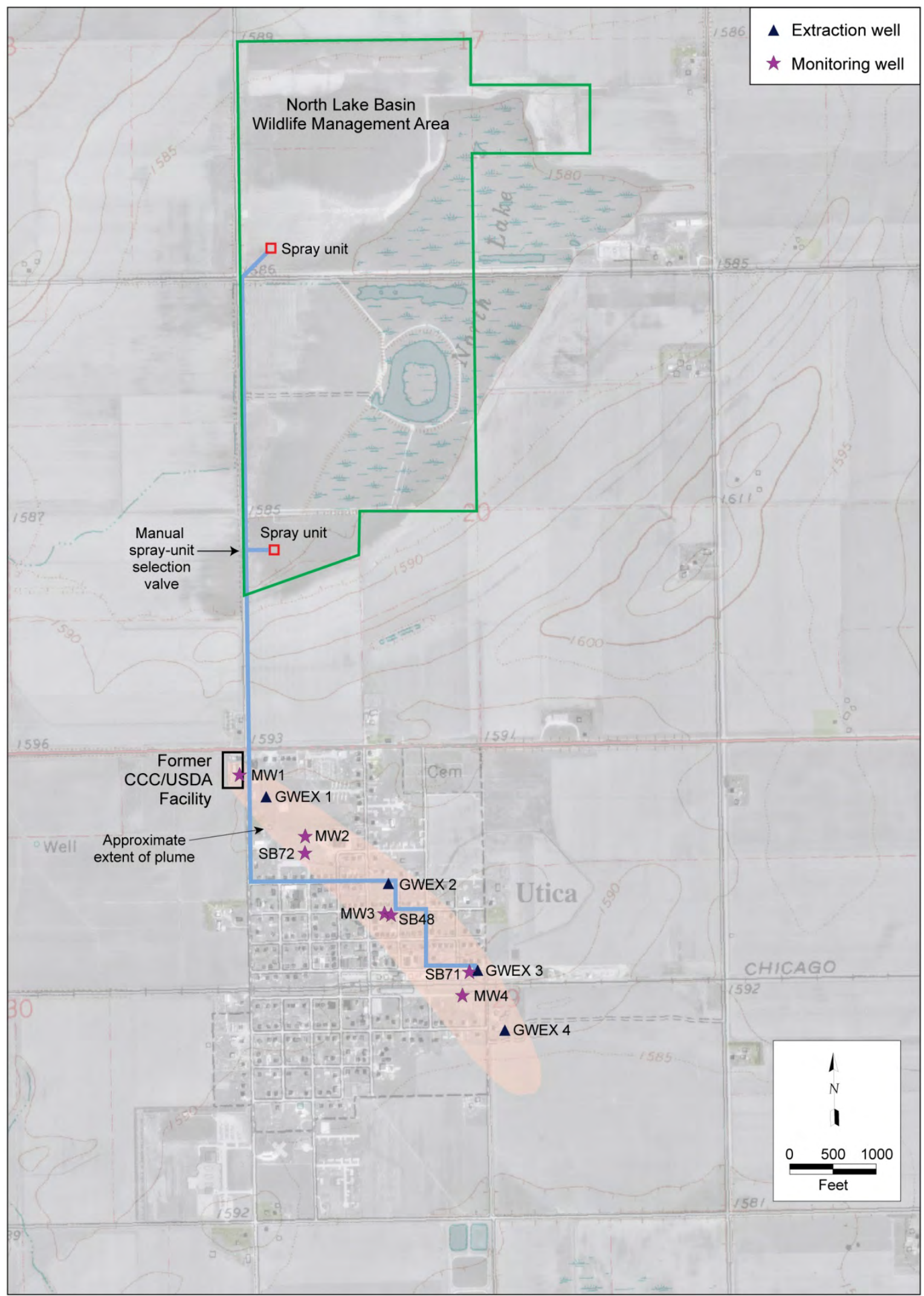

FIGURE 2.1 Locations of the restoration facilities, contaminant plume, and permanent monitoring wells at Utica. 


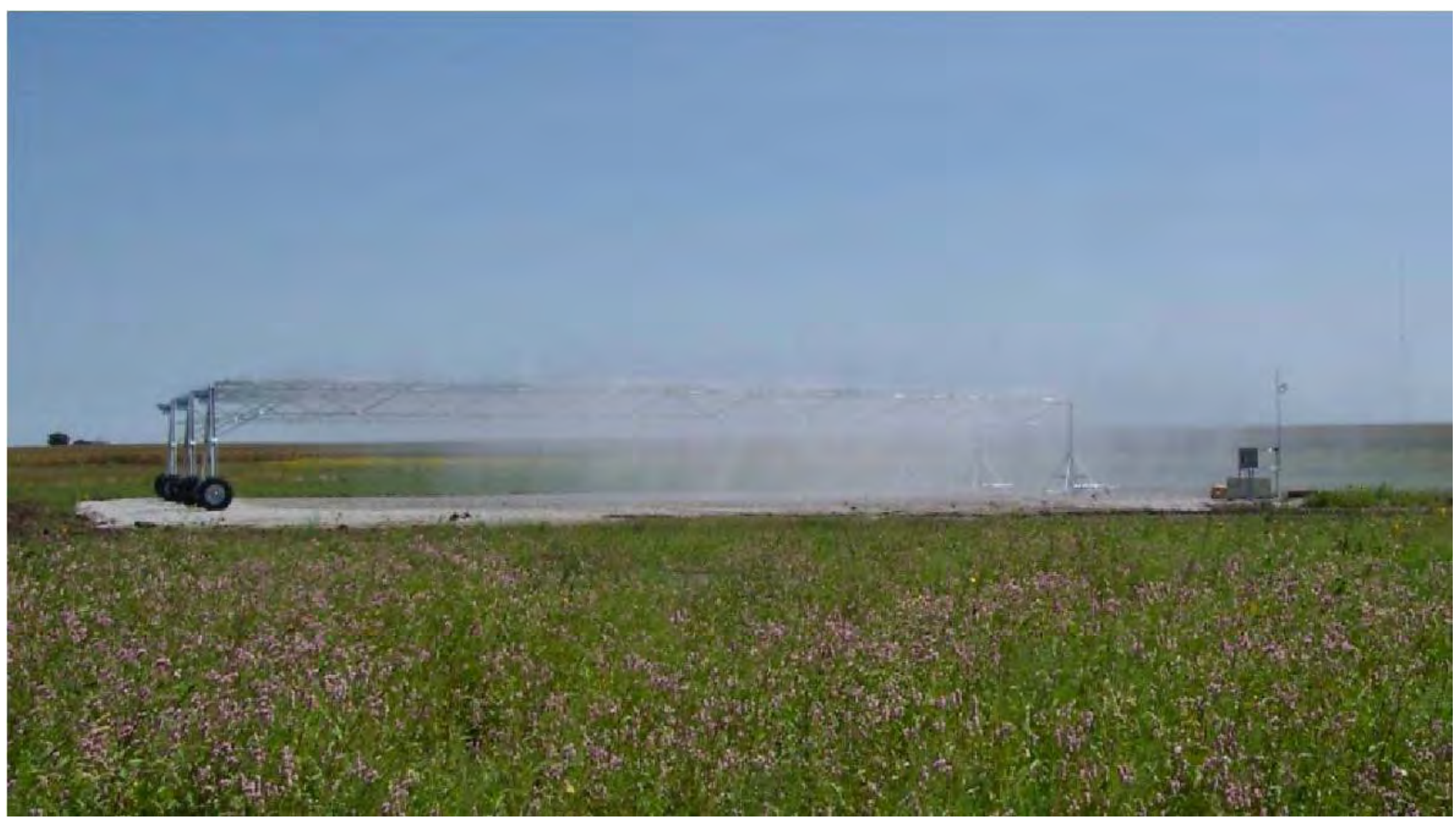

FIGURE 2.2 Spray irrigation unit in operation at Utica. 


\section{Overview of System Operations}

The groundwater restoration program at Utica is conducted in accordance with a National Pollutant Discharge Elimination System (NPDES) permit (No. NE0137456) originally granted by the State of Nebraska, Department of Environmental Quality (NDEQ), for the 5-yr period October 1, 2004, to September 30, 2009. The NDEQ (Reuel Anderson) conducted a 5-yr compliance inspection in September 2008 and gave a satisfactory review (the maximum rating available). In accord with NPDES requirements, in spring 2009 the CCC/USDA submitted an application to the NDEQ for renewal of the permit. On September 28, 2009, the CCC/USDA received notice from the NDEQ that the term of the existing NPDES permit had been extended indefinitely, pending review of the renewal application. On April 28, 2010, the CCC/USDA was informed that a draft permit, fact sheet, and public notice had been generated for the Utica site to solicit public comment regarding the proposed NPDES permit renewal, in accord with NDEQ policy. The NDEQ indicated that the public comment period was to end on June 4, 2010. To date, Argonne has received no further communications from the NDEQ concerning the draft permit; the NDEQ has been contacted for further information on the status of the renewal application. The NDEQ has indicated that, in the interim, the requirements of the original NPDES permit remain valid and in force.

\subsection{Operation of Wells GWEX1-GWEX3 and the Spray Irrigation Treatment Units}

Wells GWEX1-GWEX3 and the spray irrigation treatment units operated intermittently, under automated control, during 8 of the 12 months in the current review period (December 2009-November 2010). The treated groundwater was discharged exclusively to the south wetlands subbasin during this period, at the request of the NGPC.

Wells GWEX1-GWEX3 and the spray treatment units were not operated in JanuaryMarch 2010, because generally low $\left(<45^{\circ} \mathrm{F}\right)$ winter and early spring temperatures precluded the effective use of the spray treatment process during this period.

The operation of wells GWEX1-GWEX3 (and also well GWEX4; see Section 3.2) was suspended for the month of May 2010 to allow recovery of groundwater levels to ambient 
elevations in the shallow, contaminated aquifer undergoing restoration. This action was taken to facilitate resampling of the groundwater in the contaminated aquifer for volatile organic compounds (VOCs) analyses, in vertical profiles at selected locations along the identified plume migration pathway, as part of the 5-yr assessment of the restoration efforts at Utica recommended in the Monitoring Plan (Argonne 2004) and Recommendations for Remapping (Argonne 2009b). The results of the 5-yr resampling and evaluation are being reported separately.

\subsection{Operation of Well GWEX4 and the Conventional Air Stripper}

Well GWEX4 and the associated air stripper were operated during 5 months of the current review period.

In October 2009, repairs were completed to correct corrosion and perforation of the downhole pump and the connecting riser pipe in GWEX4. These problems had been identified during the previous review period (Argonne 2010). The well was returned to service on October 23, 2009; however, increasing sand production, variations in the flow rates from the well, and periodic fouling of the totalizing flow meter used to document the well's performance were subsequently observed. Periodic cleaning, as well as replacement of the flow meter, was performed from December 2009 until April 2010 (during the current review period) to enable the well to continue operating.

In May 2010, wells GWEX1-GWEX4 were shut down in conjunction with the 5-yr groundwater sampling program outlined in Section 3.1. Because of the problems discussed above, well GWEX4 and the air stripper were not restarted after the sampling event. In August 2010, the pump and riser pipe were removed from GWEX4 to facilitate inspection of the well casing and inlet screen, and a downhole camera survey of the well was conducted. No damage to either the casing or screen was immediately apparent; however, thick deposits of a soft material - possibly algae or bacteria - in deeper parts of the well obscured the screen and prevented detailed inspection. Well GWEX4 and the air stripper have remained out of service since that time, pending the implementation of further efforts to clean, inspect, and repair (if necessary) the well. 


\section{Groundwater Production Results}

The volumes of groundwater extracted from the Utica aquifer, treated, and discharged during the current review period are summarized in Table 4.1. Performance during the $6 \mathrm{yr}$ of system operation to date is summarized in Section 7.

\subsection{Production by Wells GWEX1-GWEX3}

Wells GWEX1-GWEX3 are equipped with electronically controlled pump drive units linked to digital flow meters that automatically and continuously adjust the flow from each well to maintain user-specified pumping rates. During this review period, the programmed flow rates for these wells were as follows:

- GWEX1, 50 gpm

- GWEX2, 200 gpm

- GWEX3, 125 gpm

The selected rates for GWEX1-GWEX3 were achieved, within $\pm 0.5 \mathrm{gpm}$, throughout the review period (Table 4.2).

Wells GWEX1-GWEX3 were pumped for approximately 3,196 hr during the review period, and they discharged approximately 71.9 million gallons (222 acre-feet) of treated water to the North Lake Basin wetlands (Table 4.1). This represents a significant increase (by approximately 21 million gallons, or $42 \%$ ) relative to the previous reporting period (Argonne 2010), but it is approximately $21 \%$ less than the maximum seasonal production total achieved by these wells to date (approximately 91 million gallons during the December 2006-November 2007 review period; see Section 7). The treated groundwater was discharged exclusively to the southern wetlands subbasin during the current review period, at the request of the NGPC. 
Operation of the spray irrigation treatment systems was suspended during January-March 2010 because of seasonally cold weather that prohibited the effective use of the spray irrigation treatment process. As described in Section 3.1, GWEX1-GWEX3 and the spray treatment units were temporarily shut down in May 2010 to facilitate sampling of the Utica groundwater under ambient (non-pumping) conditions, as part of the recommended 5-yr progress review (Argonne 2004, 2009b).

\subsection{Production by Well GWEX4}

Measured groundwater pumping rates (determined from an inline flow meter) at GWEX4 varied significantly because of the increased sand production noted in Section 3.2. The recorded flow rates ranged from approximately $46 \mathrm{gpm}$ to $91 \mathrm{gpm}$ in December 2009-April 2010. GWEX4 was shut down in May 2010 to facilitate groundwater sampling under ambient conditions for the 5-yr progress review. The GWEX4 shutdown for inspection and possible corrective action continued until the end of the review period (November 2010; Section 3.2). The volume of groundwater produced in any one complete month of pumping ranged from about 1.2 million gallons to 2.8 million gallons (Table 4.1). Approximately 11.4 million gallons (35.2 acre-feet) of groundwater was treated and discharged during the review period, at an average (365-day) pumping rate of 21.6 gpm. The average flow rate from GWEX4 during the 151 days on which it actually operated during the review period was 52.3 gpm (Table 4.2). 
TABLE 4.1 GWEX operation and groundwater production data in December 2009-November 2010.

\begin{tabular}{|c|c|c|c|c|c|c|c|c|}
\hline \multirow[b]{3}{*}{ Month } & \multicolumn{4}{|c|}{ Wells GWEX1-GWEX3 (gal) } & \multirow{2}{*}{\multicolumn{2}{|c|}{$\begin{array}{l}\text { Volume Discharged } \\
\text { to Wetlands }{ }^{\mathrm{c}} \text { (gal) }\end{array}$}} & \multicolumn{2}{|c|}{ GWEX4 } \\
\hline & \multicolumn{3}{|c|}{ Groundwater Produced ${ }^{\mathrm{a}}$} & \multirow{2}{*}{$\begin{array}{l}\text { Operating } \\
\text { Time }^{\mathrm{b}} \\
\text { (hr) }\end{array}$} & & & \multirow{2}{*}{$\begin{array}{l}\text { Groundwater } \\
\text { Produced } \\
\text { (gal) }\end{array}$} & \multirow{2}{*}{$\begin{array}{l}\text { Operating } \\
\text { Time } \\
\text { (days) }\end{array}$} \\
\hline & GWEX1 & GWEX2 & GWEX3 & & North & South & & \\
\hline Dec 09 & 4,100 & 16,000 & 10,000 & 1.4 & $-d$ & 30,100 & $2,416,842$ & 31 \\
\hline Jan 10 & - & - & - & - & - & - & $2,819,216$ & 31 \\
\hline Feb 10 & - & - & - & - & - & - & $2,535,981$ & 28 \\
\hline Mar 10 & - & - & - & - & - & - & $1,205,867$ & 31 \\
\hline Apr 10 & $1,492,700$ & $5,953,400$ & $3,736,400$ & 497.0 & - & $11,182,500$ & $2,395,148$ & 30 \\
\hline May 10 & - & - & - & - & - & - & - & - \\
\hline Jun 10 & $1,020,900$ & $4,122,700$ & $2,571,800$ & 342.9 & - & $7,715,400$ & - & - \\
\hline Jul 10 & $1,984,900$ & $8,042,900$ & $5,012,400$ & 668.5 & - & $15,040,200$ & - & - \\
\hline Aug 10 & $2,205,100$ & $8,859,700$ & $5,532,300$ & 737.6 & - & $16,597,100$ & - & - \\
\hline Sep 10 & 923,600 & $3,728,300$ & $2,300,100$ & 309.0 & - & $6,952,000$ & - & - \\
\hline Oct 10 & $1,442,000$ & $6,151,400$ & $3,734,400$ & 503.5 & - & $11,327,800$ & - & - \\
\hline Nov 10 & 468,100 & $1,577,300$ & $1,007,600$ & 135.7 & - & $3,053,000$ & - & - \\
\hline \multicolumn{9}{|l|}{ Column } \\
\hline Totals & $9,541,400$ & $38,451,700$ & $23,905,000$ & 3,196 & - & $71,898,100$ & $11,373,054$ & 151 \\
\hline
\end{tabular}

a Combined total production from wells GWEX1-GWEX4: 83,271,154 gal.

b Wells GWEX1-GWEX3 operate simultaneously.

c Total production to wetlands: $71,898,100$ gal.

d Unit not in operation. 
TABLE 4.2 Comparison of actual well production rates and target rates.

\begin{tabular}{lcc}
\hline & \multicolumn{2}{c}{ Pumping Rate (gpm) } \\
\cline { 2 - 3 } Well & Target & Actual (Net Average) ${ }^{\mathrm{a}}$ \\
& & \\
\hline & & \\
GWEX1 & 50 & 49.7 \\
GWEX2 & 200 & 200.5 \\
GWEX3 & 125 & 124.7 \\
GWEX4 & $60-65$ & 52.3 \\
\hline
\end{tabular}

a Average for actual periods of operation. 


\section{Groundwater Treatment Results}

Treated groundwater at Utica is discharged under NPDES permit No. NE0137456, issued by the NDEQ on October 1, 2004. The original (5-yr) term of this permit has been indefinitely extended by the NDEQ, pending the NDEQ's finalization of an application for renewal of the permit submitted by the CCC/USDA during the previous (December 2008-November 2009) review period (Argonne 2010).

To comply with the NPDES requirements, samples of treated groundwater are collected monthly, as follows:

- At the outlet of the air stripping unit at GWEX4.

- From the spray discharge at each of the irrigation treatment units (during months of operation).

The samples are analyzed to determine the residual concentrations of carbon tetrachloride in the treated groundwater and the $\mathrm{pH}$ of the effluent. The results of these analyses are reported to the NDEQ quarterly.

The discharges of treated groundwater at Utica are considered by the NDEQ to contribute to the surface waters of the state. On this basis, the NDEQ has specified the following compliance limits for the outfall from each treatment unit:

- A target maximum residual carbon tetrachloride concentration of $44.2 \mu \mathrm{g} / \mathrm{L}$.

- $\quad$ An acceptable pH range of 6.5 to 9.0.

In conjunction with the compliance sampling, Argonne collects monthly samples of the untreated groundwater from each extraction well. The samples are analyzed for VOCs to enable estimation of the following: 
- Carbon tetrachloride removal efficiencies for the treatment units.

- Quantities of carbon tetrachloride removed from the contaminated aquifer.

The results of the sampling and analysis activities during the review period are summarized in Tables 5.1 and 5.2.

\subsection{Results for Wells GWEX1-GWEX3, with Treatment by Spray Irrigation}

The concentrations of carbon tetrachloride found in the untreated groundwater from extraction wells GWEX2 and GWEX3 were highest upon initial start-up of the wells in April 2010 (following shutdown for the preceding winter). The concentrations declined in June and then varied with no clear trend during the remainder of review period (Table 5.1). Carbon tetrachloride concentrations at GWEX2 ranged from $21 \mu \mathrm{g} / \mathrm{L}$ to $48 \mu \mathrm{g} / \mathrm{L}$, while at GWEX3 the levels ranged from $21 \mu \mathrm{g} / \mathrm{L}$ to $66 \mu \mathrm{g} / \mathrm{L}$.

Observed carbon tetrachloride levels at upgradient extraction well GWEX1 were highest at the beginning and end of the review period (in December 2009 and November 2010), with a minimum in June 2010. The observed concentrations at GWEX1 showed no apparent correlation to the concentrations observed at GWEX2 and GWEX3. Carbon tetrachloride concentrations at GWEX1 ranged from $23 \mu \mathrm{g} / \mathrm{L}$ (in June 2010) to 58-60 $\mu \mathrm{g} / \mathrm{L}$ (in December 2009 and November 2010).

The groundwater produced from wells GWEX1-GWEX3 is combined into a single stream for conveyance to the wetlands via a common pipeline. This combined flow is also sampled monthly as an indicator of the weighted average concentration of carbon tetrachloride in the untreated groundwater supplied to the spray irrigation treatment units. The measured concentrations in the combined flow (Table 5.1) varied from $22 \mu \mathrm{g} / \mathrm{L}$ to $53 \mu \mathrm{g} / \mathrm{L}$ during the current monitoring period. The temporal variations in concentration observed in the combined flow stream generally mirrored those observed at wells GWEX2 and GWEX3, which together contribute approximately $87 \%$ of the total discharge from the extraction well system. 
Treated groundwater sprayed from the irrigation units is collected for analysis at the following four locations at the treatment site during each sampling event:

- Beneath the center point of the "west" irrigation span.

- Beneath the center point of the “center” irrigation span.

- Beneath the center point of the "east” irrigation span.

- At a fourth location visually chosen to reflect the estimated site of maximum spray outfall ("max" value at a position varying from month to month, depending on the prevailing wind and spray conditions at the time of sampling).

The results (Table 5.1) show that the concentrations in all spray samples collected during the review period were below the maximum contaminant level (MCL) of $5.0 \mu \mathrm{g} / \mathrm{L}$ promulgated by the U.S. Environmental Protection Agency for carbon tetrachloride in drinking water. The maximum carbon tetrachloride level identified for a single sample of spray discharged from the irrigation treatment units was $1.6 \mu \mathrm{g} / \mathrm{L}$. The average concentration of carbon tetrachloride in the treated groundwater discharged to the wetlands was approximately $0.2 \mu \mathrm{g} / \mathrm{L}$. The concentrations of carbon tetrachloride in all spray samples were below the maximum target concentration (44.2 $\mu \mathrm{g} / \mathrm{L})$ allowed under the NPDES permit, by roughly an order of magnitude.

The results of the groundwater and spray sample analyses suggest the following minimum carbon tetrachloride removal efficiency values for the spray irrigation treatment process:

- $\quad$ More than $94 \%$ (based on data for individual samples).

- Approximately 99\% (based on the average concentration delivered to the wetlands during the review period). 
The results of $\mathrm{pH}$ measurements recorded for samples of the treated spray discharge are presented in Table 5.2. In all cases, the observed $\mathrm{pH}$ levels (7.40 to 8.73) were within the acceptable range (6.5 to 9.0) specified under the NPDES permit.

\subsection{Results for Well GWEX4, with Treatment by Air Stripping}

Low concentrations of carbon tetrachloride were detected in the untreated groundwater produced by GWEX4 (3.5 $\mu \mathrm{g} / \mathrm{L}$ to $11 \mu \mathrm{g} / \mathrm{L}$; Table 5.1) for the 5 months (December 2009-April 2010) in which this well was operated during the current review period. The carbon tetrachloride concentration in the untreated groundwater dropped below the MCL of $5.0 \mu \mathrm{g} / \mathrm{L}$ in February 2010, but the concentration returned to levels exceeding the MCL in March and April 2010. Carbon tetrachloride was not detected in the effluent from the air stripping unit throughout the review period, indicating a carbon tetrachloride removal efficiency of $>99 \%$ for this process. Measured $\mathrm{pH}$ levels in all samples of the air stripper effluent (7.98 to 8.36; Table 5.2) were within the acceptable range (6.5 to 9.0) specified under the NPDES permit.

\subsection{Estimated Removal of Carbon Tetrachloride from the Utica Aquifer}

The groundwater production and carbon tetrachloride concentration data presented in Tables 4.1 and 5.1, respectively, can be used to estimate the total quantity of carbon tetrachloride extracted by wells GWEX1-GWEX4 from December 1, 2009, to November 30, 2010. The results of these calculations, summarized in Table 5.3, indicate that approximately $8.7 \mathrm{~kg}$ (1.4 gal) of carbon tetrachloride was removed from the Utica aquifer by GWEX1-GWEX4 during the present review period. In the previous period (December 2008-November 2009), approximately $9.3 \mathrm{~kg}$ (1.5 gal) of carbon tetrachloride was removed. These values are significantly lower than the quantities of carbon tetrachloride recovered annually from the aquifer (23-34 kg/yr) during the first $3 \mathrm{yr}$ of operation of the Utica remedial systems, in November 2004-November 2007.

The reduced quantities of carbon tetrachloride removed from the Utica aquifer in the current review period and in December 2007-November 2009 reflect decreasing trends in the 
concentrations of carbon tetrachloride observed in the groundwater produced by wells GWEX2GWEX4 (see Section 5.4), as well as the limited operation of GWEX1-GWEX3 and the spray treatment units (in December 2007-November 2009) and GWEX4 (in December 2009November 2010) that have been possible during these review periods (Section 3.1). No decrease in the volumetric throughput (when operating) or contaminant removal efficiency of the groundwater treatment systems was observed during the current period.

\subsection{Sampling of Monitoring Wells and Apparent Carbon Tetrachloride Concentration Trends in the Utica Groundwater}

Table 5.4 summarizes construction data for the monitoring wells, as well as the results of groundwater sampling and analyses for VOCs during the current review period. Complete monitoring data for wells MW1-MW4, since sampling at these points began in September 2005, are depicted in Figure 5.1. Figures 5.2-5.5 summarize the carbon tetrachloride concentrations measured at GWEX1-GWEX4, respectively, since the routine operation and sampling of these wells began in November 2004.

Except for MW1, carbon tetrachloride concentrations at all of the monitoring wells (Figure 5.1) have been relatively stable, with no persistent rising or falling trends. Carbon tetrachloride concentrations at MW1 have been consistently greater than those at downgradient monitoring wells MW2-MW4 (Figures 2.1 and 5.1). Concentrations at MW1 increased to a maximum in June-October 2007 (Figure 5.1), decreased significantly from October 2007 to November 2008, and then remained relatively stable $(100-131 \mu \mathrm{g} / \mathrm{L})$ during the December 2008November 2009 review period. The concentrations at MW1 oscillated between values of $87 \mu \mathrm{g} / \mathrm{L}$ and 152-185 $\mu \mathrm{g} / \mathrm{L}$ during the current (December 2009-November 2010) review period and showed no clear rising or falling trend (Figure 5.1 and Table 5.4).

The identified carbon tetrachloride concentrations at downgradient extraction wells GWEX2-GWEX4 (Figures 5.3-5.5) have declined slowly during the period of record, although short-term variability is apparent within the generally decreasing trend for each well. At GWEX2 and GWEX3, a pattern of relatively higher initial concentrations at each well upon seasonal (spring) start-up is apparent, followed by generally declining contaminant levels during periods 
of continuous operation. In contrast, carbon tetrachloride concentrations at upgradient well GWEX1 (Figures 2.1 and 5.2) have shown no clear long-term trend, but the values appear to increase during seasonal periods of continuous operation.

Wells MW1 and GWEX1 are located, respectively, on and near the former CCC/USDA facility property (Figure 2.1). Together, the data for MW1 and GWEX1 (Figures 5.1 and 5.2) might reflect localized influx of carbon tetrachloride from residual contamination in the soils beneath the former CCC/USDA facility to the upgradient shallow groundwater (Argonne 2000, 2003). The stable or decreasing contaminant levels observed at all of the downgradient monitoring and GWEX wells demonstrate, however, that GWEX1 is presently operating effectively as an upgradient capture well.

\subsection{Evaluation of Groundwater Inorganic Geochemistry}

In accord with the approved Monitoring Plan (Argonne 2004), samples of the untreated groundwater from individual extraction wells GWEX1-GWEX4 and the (treated) effluent from the air stripper at GWEX4 are collected annually and submitted for inorganic geochemical analyses. Samples from wells GWEX1-GWEX3 and their combined (untreated) effluent were collected for analysis during the current review period in October 2010. Corresponding samples could not be collected from GWEX4 or the treated effluent from this well, because the well remained out of service from May 2010 to the end of the review period (November 2010).

The results of the geochemical analyses are in Table 5.5, together with equivalent data for these sampling locations in the December 2007-November 2008 and December 2008-November 2009 review periods. The October 2010 results indicate no substantial changes in the geochemistry of the groundwater produced by GWEX1-GWEX3 for treatment and discharge to the North Lake Basin wetlands during the current and previous review periods. The results in Table 5.5 indicate a similar finding for the untreated groundwater and treated effluent obtained from GWEX4 during the current and previous review periods. 
TABLE 5.1 Analytical results for carbon tetrachloride in untreated groundwater samples and treated effluent samples in December 2009November 2010.

\begin{tabular}{|c|c|c|c|c|c|c|c|c|c|c|c|c|c|c|}
\hline \multirow[b]{3}{*}{ Month } & \multicolumn{14}{|c|}{ Carbon Tetrachloride Concentration ( $\mu \mathrm{g} / \mathrm{L})$} \\
\hline & \multicolumn{4}{|c|}{ GWEX1-GWEX3 Untreated } & \multicolumn{4}{|c|}{ North Spray Unit Effluent } & \multicolumn{4}{|c|}{ South Spray Unit Effluent } & \multirow{2}{*}{$\begin{array}{l}\text { GWEX4 } \\
\text { Untreated }\end{array}$} & \multirow{2}{*}{$\begin{array}{l}\text { Stripper } \\
\text { Effluent }\end{array}$} \\
\hline & GWEX1 & GWEX2 & GWEX3 & Mixed $^{a}$ & West $^{\mathrm{b}}$ & Center ${ }^{b}$ & East $^{b}$ & $\operatorname{Max}^{\mathrm{C}}$ & West $^{\mathrm{b}}$ & Center ${ }^{b}$ & East $^{b}$ & $\operatorname{Max}^{\mathrm{C}}$ & & \\
\hline Dec 09 & 60 & 31 & 36 & 28 & $-d$ & - & - & - & 1.3 & 1.6 & $N D^{e}$ & ND & 5.2 & ND \\
\hline Jan 10 & - & - & - & - & - & - & - & - & - & - & - & - & 11 & ND \\
\hline Feb 10 & - & - & - & - & - & - & - & - & - & - & - & - & 3.5 & ND \\
\hline Mar 10 & - & - & - & - & - & - & - & - & - & - & - & - & 8.4 & ND \\
\hline Apr 10 & 48 & 48 & 66 & 53 & - & - & - & - & ND & ND & ND & ND & 10 & ND \\
\hline May 10 & - & - & - & - & - & - & - & - & - & - & - & - & - & - \\
\hline Jun 10 & 23 & 32 & 45 & 35 & - & - & - & - & ND & ND & $0.4 \mathrm{~J}^{f}$ & ND & - & - \\
\hline Jul 10 & 38 & 27 & 27 & 28 & - & - & - & - & ND & $0.4 \mathrm{~J}$ & ND & ND & - & - \\
\hline Aug 10 & 41 & 21 & 20 & 22 & - & - & - & - & ND & ND & ND & ND & - & - \\
\hline Sep 10 & 48 & 25 & 23 & 27 & - & - & - & - & ND & $0.5 \mathrm{~J}$ & ND & ND & - & - \\
\hline Oct 10 & 45 & 22 & 21 & 25 & - & - & - & - & $0.6 \mathrm{~J}$ & ND & $0.6 \mathrm{~J}$ & ND & - & - \\
\hline Nov 10 & 58 & 27 & 26 & 31 & - & - & - & - & ND & ND & ND & ND & - & - \\
\hline
\end{tabular}

a Analytical results for samples from the combined flows of GWEX1-GWEX3.

b Samples of spray collected below the center point of the respective irrigation span.

c Samples of spray collected at the estimated location of maximum spray outfall.

d Unit not in operation

e ND, not detected at a method detection limit of $0.1 \mu \mathrm{g} / \mathrm{L}$.

f Qualifier J indicates an estimated concentration below the quantitation limit of $1.0 \mu \mathrm{g} / \mathrm{L}$ for the purge-and-trap method. 
TABLE 5.2 Values for $\mathrm{pH}$ in untreated groundwater samples and treated effluent samples in December 2009-November 2010.

\begin{tabular}{|c|c|c|c|c|c|c|c|c|}
\hline \multirow[b]{3}{*}{ Month } & \multicolumn{8}{|c|}{$\mathrm{pH}$} \\
\hline & \multicolumn{4}{|c|}{ GWEX1-GWEX3 Untreated } & \multirow{2}{*}{$\begin{array}{l}\text { North } \\
\text { Spray } \\
\text { Unit }^{b}\end{array}$} & \multirow{2}{*}{$\begin{array}{l}\text { South } \\
\text { Spray } \\
\text { Unit }^{b}\end{array}$} & \multirow{2}{*}{$\begin{array}{c}\text { GWEX4 } \\
\text { Untreated }\end{array}$} & \multirow{2}{*}{$\begin{array}{l}\text { Stripper } \\
\text { Effluent }\end{array}$} \\
\hline & GWEX1 & GWEX2 & GWEX3 & Mixed $^{\mathrm{a}}$ & & & & \\
\hline Dec 09 & 7.38-7.42 & 7.11-7.14 & $6.97-7.07$ & $7.48-7.82$ & $-^{\mathrm{c}}$ & $8.27-8.37$ & $7.00-7.04$ & 8.32-8.36 \\
\hline Jan 10 & - & - & - & - & - & - & $6.84-6.92$ & $8.18-8.36$ \\
\hline Feb 10 & - & - & - & - & - & - & $7.60-7.65$ & $8.35-8.36$ \\
\hline Mar 10 & - & - & - & - & - & - & $6.74-6.86$ & 7.98 \\
\hline Apr 10 & 7.01-7.08 & $6.94-6.96$ & $6.90-6.91$ & 7.03-7.15 & - & $8.14-8.20$ & $6.70-6.77$ & 8.18 \\
\hline May 10 & - & - & - & - & - & - & - & - \\
\hline Jun 10 & 7.08-7.10 & $6.92-6.96$ & $6.90-6.95$ & 7.12-7.16 & - & $8.14-8.21$ & - & - \\
\hline Jul 10 & $7.62-8.00$ & 7.38 & $7.35-7.44$ & $7.60-7.74$ & - & $8.63-8.73$ & - & - \\
\hline Aug 10 & $6.60-6.81$ & $6.70-6.98$ & $6.81-7.00$ & 7.34-7.78 & - & $8.20-8.44$ & - & - \\
\hline Sep 10 & 7.14-7.28 & $6.99-7.04$ & $6.85-6.98$ & 7.39-7.91 & - & $8.02-8.08$ & - & - \\
\hline Oct 10 & $6.96-7.02$ & $6.83-6.84$ & $6.90-6.92$ & 7.01-7.03 & - & $8.27-8.35$ & - & - \\
\hline Nov 10 & $7.16-7.25$ & $6.99-7.06$ & 6.89-6.91 & 7.30-7.31 & - & $7.40-7.91$ & - & - \\
\hline
\end{tabular}

a Ranges of values for multiple measurements of the combined flows of GWEX1-GWEX3.

b Ranges of values for spray samples collected at multiple locations at the discharge site.

c Unit not in operation. 
TABLE 5.3 Estimation of carbon tetrachloride removed from the Utica aquifer in December 2009-November 2010. ${ }^{\mathrm{a}}$

\begin{tabular}{|c|c|c|c|c|c|c|c|c|}
\hline \multirow[b]{4}{*}{ Month } & \multicolumn{4}{|c|}{ GWEX1-GWEX3 } & \multicolumn{4}{|c|}{ GWEX4 } \\
\hline & \multirow{2}{*}{\multicolumn{2}{|c|}{ Groundwater Extracted }} & \multicolumn{2}{|c|}{ Carbon Tetrachloride } & & & \multicolumn{2}{|c|}{ Carbon Tetrachloride } \\
\hline & & & & $\begin{array}{l}\text { Calculated } \\
\text { Amount }\end{array}$ & \multicolumn{2}{|c|}{$\begin{array}{l}\text { Groundwater } \\
\text { Extracted }\end{array}$} & \multirow[b]{2}{*}{$\begin{array}{l}\text { Concentration } \\
\qquad(\mu \mathrm{g} / \mathrm{L})\end{array}$} & \multirow{2}{*}{$\begin{array}{l}\text { Calculated } \\
\text { Amount } \\
\text { Removed } \\
(\mathrm{kg})\end{array}$} \\
\hline & (gal) & $(\mathrm{L})$ & $\begin{array}{l}\text { Concentration } \\
(\mu \mathrm{g} / \mathrm{L})\end{array}$ & $\begin{array}{l}\text { Removed } \\
\quad(\mathrm{kg})\end{array}$ & (gal) & $(\mathrm{L})$ & & \\
\hline Dec 09 & 301,00 & 113,959 & 28 & 0.003 & $2,416,842$ & $9,150,164$ & 7.2 & 0.07 \\
\hline Jan 10 & $-^{\mathrm{c}}$ & - & - & - & $2,819,216$ & $10,673,552$ & 11 & 0.12 \\
\hline Feb 10 & - & - & - & - & $2,535,981$ & $9,601,224$ & 3.5 & 0.03 \\
\hline Mar 10 & - & - & - & - & $1,205,867$ & $4,565,412$ & 8.4 & 0.04 \\
\hline Apr 10 & $11,182,500$ & $42,336,945$ & 53 & 2.24 & $2,395,148$ & $9,068,030$ & 10 & 0.09 \\
\hline May 10 & - & - & - & - & - & - & - & - \\
\hline Jun 10 & $7,715,400$ & $29,210,504$ & 35 & 1.02 & - & - & - & - \\
\hline Jul 10 & $15,040,200$ & $56,942,197$ & 28 & 1.59 & - & - & - & - \\
\hline Aug 10 & $16,597,100$ & $62,836,621$ & 22 & 1.38 & - & - & - & - \\
\hline Sep 10 & $6,952,000$ & $26,320,272$ & 27 & 0.71 & - & - & - & - \\
\hline Oct 10 & $11,327,800$ & $42,887,051$ & 25 & 1.07 & - & - & - & - \\
\hline Nov 10 & $3,053,000$ & $11,558,658$ & 31 & 0.36 & - & - & - & - \\
\hline TOTAL & & & & 8.39 & & & & 0.35 \\
\hline
\end{tabular}

a Total carbon tetrachloride removed from the aquifer: $8.74 \mathrm{~kg}$.

b Concentration in untreated samples of the combined flow from wells GWEX1-GWEX3.

c Unit not in operation. 
TABLE 5.4 Well construction data and analytical results for carbon tetrachloride in groundwater samples from the permanant monitoring wells.

\begin{tabular}{|c|c|c|c|c|c|c|}
\hline \multirow[b]{3}{*}{ Well } & \multicolumn{2}{|c|}{ Depth (ft BGL) } & & & & \\
\hline & \multirow[b]{2}{*}{ Total } & \multirow{2}{*}{$\begin{array}{l}\text { Screened } \\
\text { Interval }\end{array}$} & \multicolumn{4}{|c|}{ Carbon Tetrachloride ( $\mu \mathrm{g} / \mathrm{L})$} \\
\hline & & & Jan 10 & Apr 10 & Jul 10 & Oct 10 \\
\hline SB48 & 98.5 & $83.5-93.5^{a}$ & $N D^{b}$ & ND & ND & ND \\
\hline SB71 & 94.2 & 84-94 & 0.6 & ND & ND & ND \\
\hline SB72 & 122.3 & 82.6-112.6 & 8.7 & 6.1 & 3.3 & 1.3 \\
\hline MW1 & 105 & 85-100 & 152 & 87 & 185 & 87 \\
\hline MW2 & 115 & $90-110$ & 25 & $14-15$ & 35 & 11 \\
\hline MW3 & 125 & $100-120$ & 67 & $36-41$ & 16 & 37 \\
\hline MW4 & 125 & $100-120$ & $6.0-6.7$ & 4.4-4.9 & 3.0 & 2.4 \\
\hline
\end{tabular}

a Ranges of values represent both primary samples and quality control replicates and duplicates.

b ND, not detected at a method detection limit of $0.1 \mu \mathrm{g} / \mathrm{L}$. 
TABLE 5.5 Comparison of inorganic geochemical results for untreated groundwater samples and treated effluent samples.

\begin{tabular}{|c|c|c|c|c|c|c|c|c|c|c|c|c|c|c|c|c|c|c|}
\hline \multirow[b]{3}{*}{ Analyte } & \multicolumn{18}{|c|}{ Concentration (mg/L) } \\
\hline & \multicolumn{3}{|c|}{ GWEX1 } & \multicolumn{3}{|c|}{ GWEX2 } & \multicolumn{3}{|c|}{ GWEX3 } & \multicolumn{3}{|c|}{ GWEX1-GWEX3 } & \multicolumn{3}{|c|}{ GWEX4 Untreated } & \multicolumn{3}{|c|}{ GWEX4 Effluent } \\
\hline & Nov 2008 & Nov 2009 & Oct 2010 & Nov 2008 & Nov 2009 & Oct 2010 & Nov 2008 & Nov 2009 & Oct 2010 & Nov 2008 & Nov 2009 & Oct 2010 & Nov 2008 & Nov 2009 & Oct 2010 & Nov 2008 & Nov 2009 & Oct 2010 \\
\hline Aluminum & $<0.2^{\mathrm{a}}$ & $<0.2$ & $<0.2$ & $<0.2$ & $<0.2$ & $<0.2$ & $<0.2$ & $<0.2$ & $<0.2$ & $-^{\mathrm{b}}$ & - & $<0.2$ & $<0.2$ & $<0.2$ & - & $<0.2$ & $<0.2$ & - \\
\hline Calcium & 83.9 & 82 & 87 & 95.4 & 92 & 88 & 99.7 & 97 & 100 & - & - & 92 & 110 & 110 & - & 110 & 110 & - \\
\hline Chloride & 13 & 18 & 21 & 16 & 19 & 22 & 28 & 23 & 31 & - & - & 25 & 31 & 29 & - & 32 & 29 & - \\
\hline & $<0.1$ & $<0.1$ & $<0.2$ & $<0.1$ & $<0.1$ & $<0.2$ & $<0.1$ & $<0.1$ & $<0.2$ & - & - & $<0.2$ & $<0.1$ & $<0.1$ & - & $<0.1$ & $<0.1$ & - \\
\hline Magnesium & 13.2 & 13 & 14 & 15.6 & 15 & 15 & 16.1 & 16 & 17 & - & - & 15 & 17.7 & 18 & - & 17.8 & 19 & - \\
\hline Manganese & $<0.015$ & $<0.015$ & $<0.015$ & $<0.015$ & $<0.015$ & $<0.015$ & $<0.015$ & $<0.015$ & $<0.015$ & - & - & $<0.015$ & $<0.015$ & $<0.015$ & - & $<0.015$ & $<0.015$ & - \\
\hline Phosphate & 0.40 & $<0.20 \mathrm{H}^{\mathrm{c}}$ & $<0.2 \mathrm{H}$ & 0.39 & 0.37 & $<0.2 \mathrm{H}$ & 0.46 & $<0.20 \mathrm{H}$ & $<0.2 \mathrm{H}$ & - & - & $<0.2 \mathrm{H}$ & 0.42 & $<0.20 \mathrm{H}$ & - & 0.40 & $<0.20 \mathrm{H}$ & - \\
\hline Phosphorus & 0.307 & 0.28 & 0.3 & 0.291 & 0.31 & 0.31 & 0.258 & 0.31 & 0.31 & - & - & 0.25 & 0.294 & 0.34 & - & 0.295 & 0.3 & - \\
\hline Potassium & 5.38 & 5.3 & 5.3 & 5.83 & 6.2 & 6 & 6.48 & 6.4 & 6.6 & - & - & 6.5 & 6.70 & 6.5 & - & 6.50 & 7 & - \\
\hline Silicon & 16.9 & 16 & 16 & 17.2 & 17 & 16 & 17.9 & 17 & 17 & - & - & 15 & 18.2 & 17 & - & 18.2 & 18 & - \\
\hline Sodium & 34 & 31 & 37 & 41.6 & 36 & 39 & 37.8 & 40 & 46 & - & - & 43 & 44.6 & 41 & - & 44.8 & 47 & - \\
\hline Sulfate & 26 & 20 & 22 & 38 & 32 & 38 & 52 & 38 & 41 & - & - & 33 & 55 & 48 & - & 56 & 48 & - \\
\hline Zinc & 0.0395 & 0.025 & $<0.02$ & $<0.02$ & $<0.02$ & 0.021 & $<0.02$ & $<0.02$ & $<0.02$ & - & - & $<0.02$ & $<0.02$ & $<0.02$ & - & $<0.02$ & $<0.02$ & - \\
\hline Nitrate (as N) & 18 & $10 \mathrm{H}$ & $10 \mathrm{H}$ & 13 & $11 \mathrm{H}$ & $12 \mathrm{H}$ & 18 & $16 \mathrm{H}$ & $18 \mathrm{H}$ & - & - & $14 \mathrm{H}$ & 20 & $19 \mathrm{H}$ & - & 21 & $19 \mathrm{H}$ & - \\
\hline
\end{tabular}

a Analyte not identified at analytical method detection limit indicated.

b No analysis.

c Qualifier $\mathrm{H}$ indicates that the holding time before analysis was exceeded. 


\section{Carbon Tetrachloride Concentrations at Monitoring Wells}

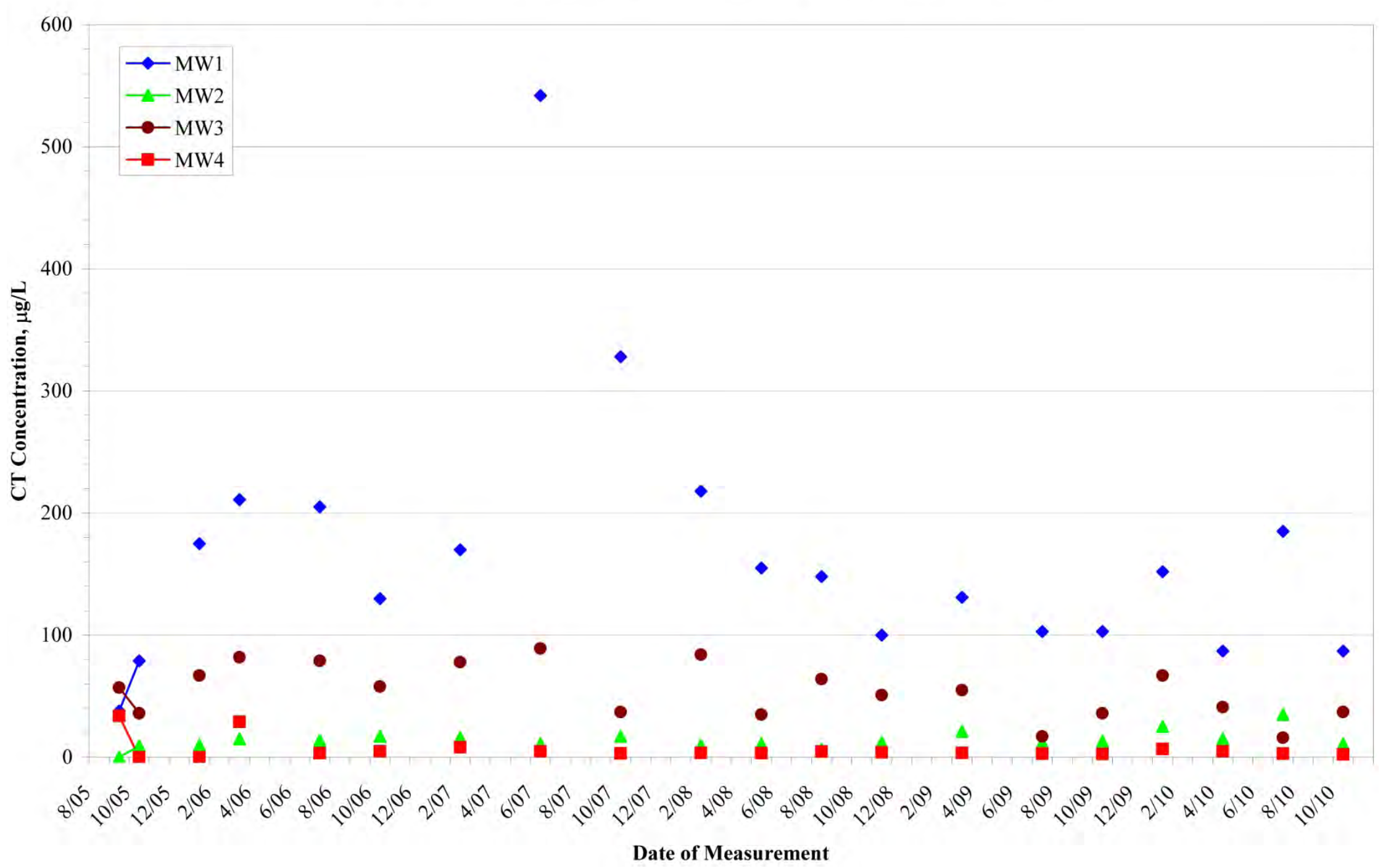

FIGURE 5.1 Carbon tetrachloride concentrations ( $\mu \mathrm{g} / \mathrm{L}$ ) at monitoring wells MW1-MW4, September 2005 to November 2010. 


\section{Carbon Tetrachloride Concentrations at Extraction Well GWEX1}

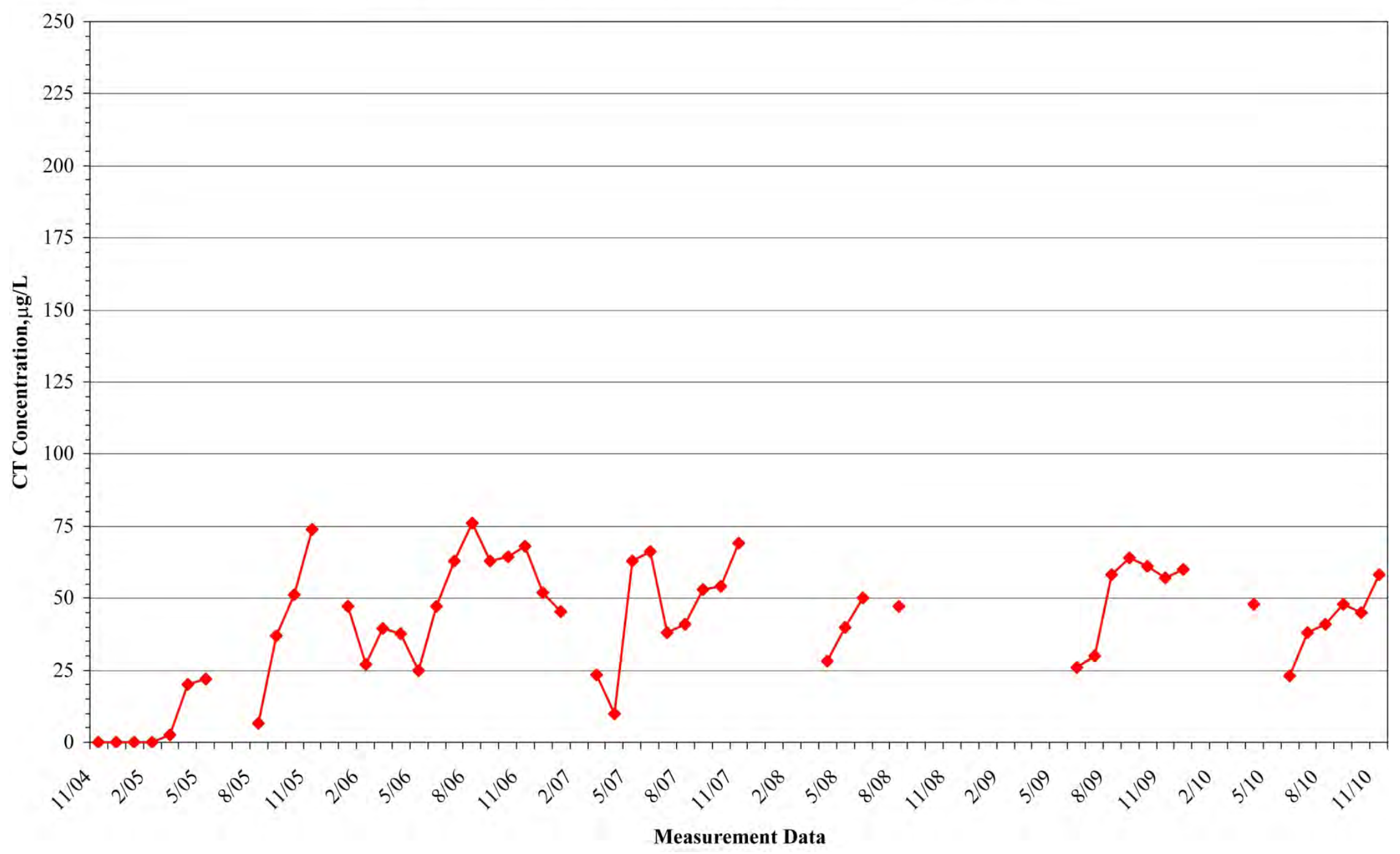

FIGURE 5.2 Carbon tetrachloride concentrations ( $\mu \mathrm{g} / \mathrm{L}$ ) at extraction well GWEX1, November 2004 to November 2010. 


\section{Carbon Tetrachloride Concentrations at Extraction Well GWEX2}

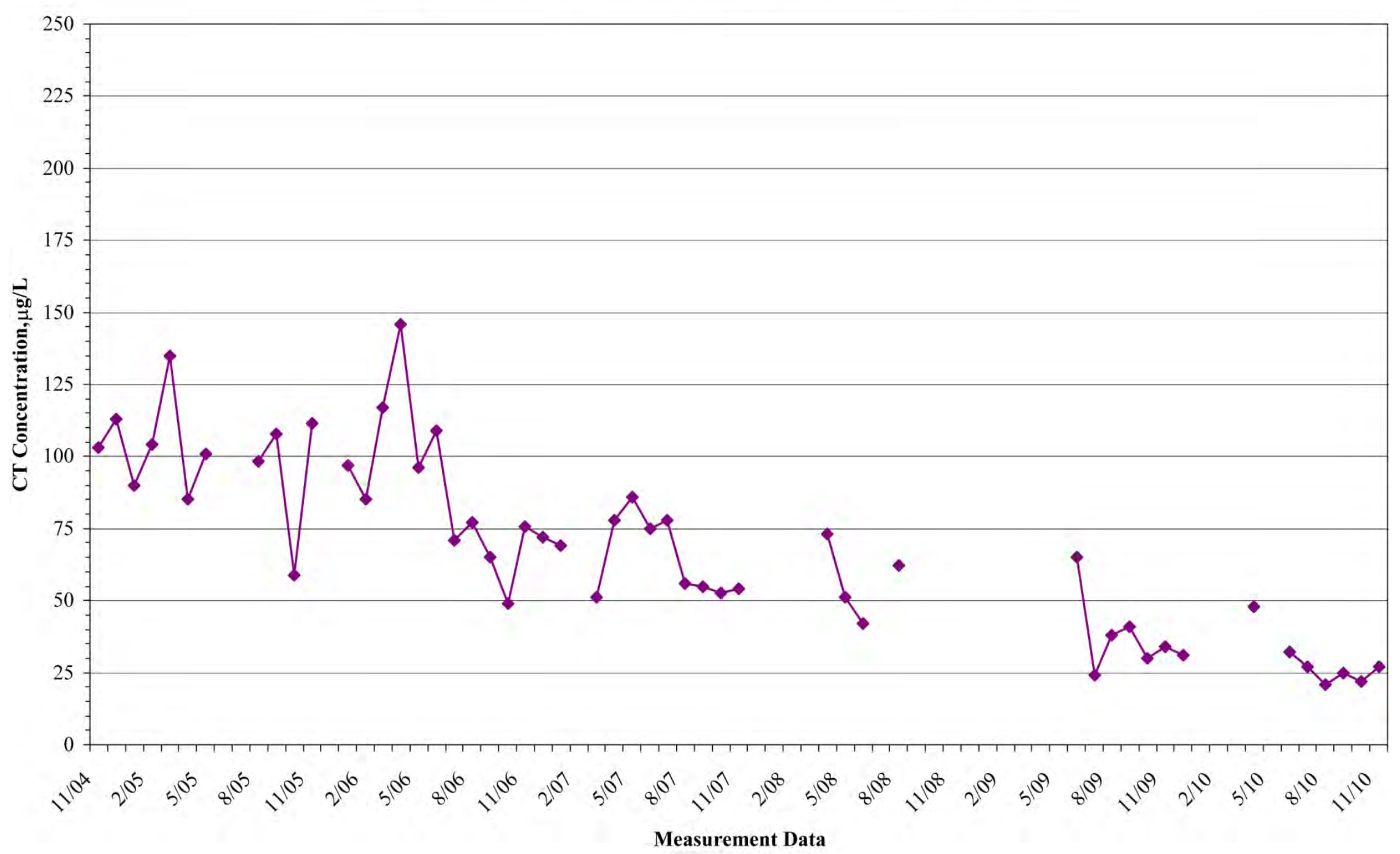

FIGURE 5.3 Carbon tetrachloride concentrations ( $\mu \mathrm{g} / \mathrm{L}$ ) at extraction well GWEX2, November 2004 to November 2010. 


\section{Carbon Tetrachloride Concentrations at Extraction Well GWEX3}

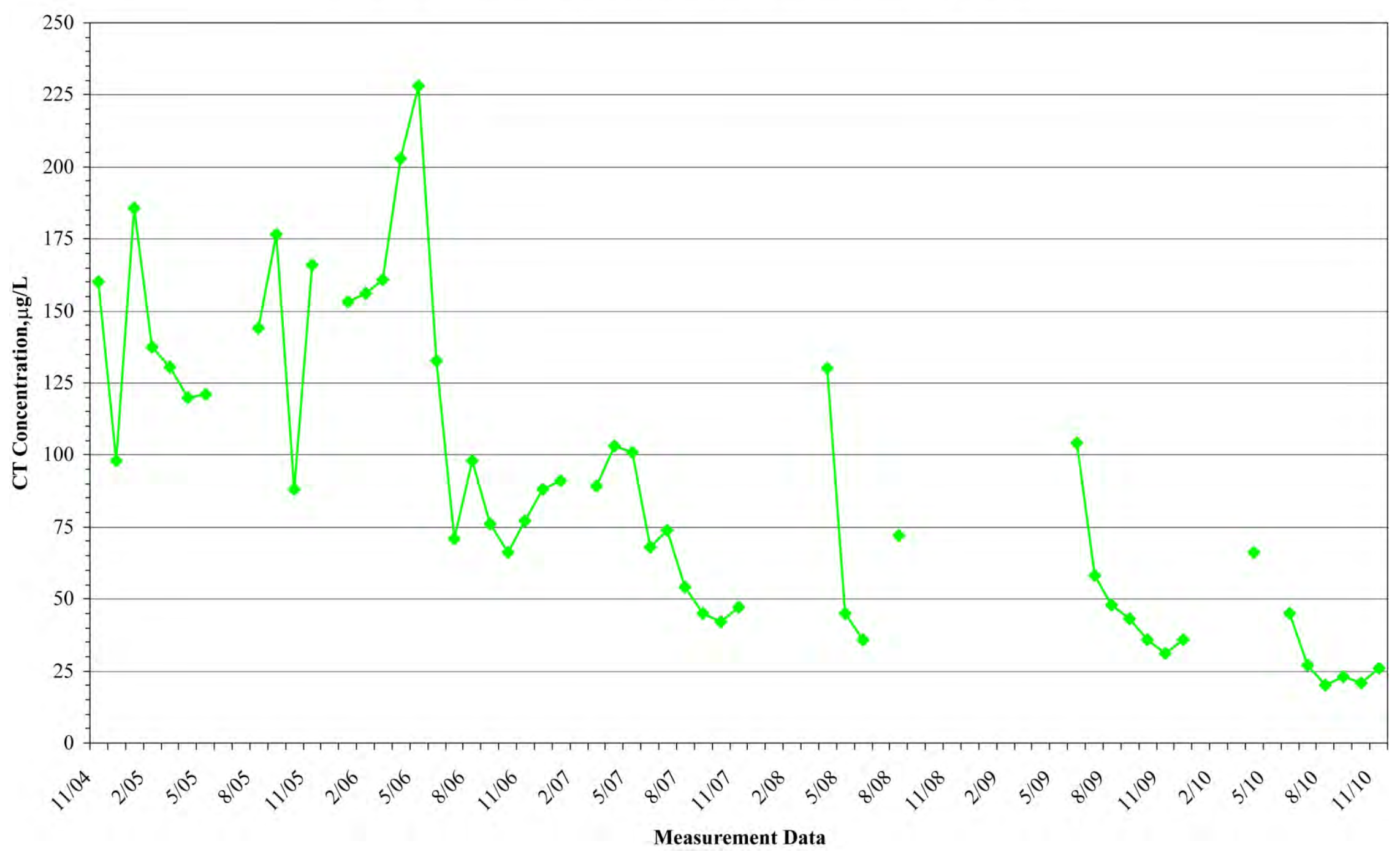

FIGURE 5.4 Carbon tetrachloride concentrations ( $\mu \mathrm{g} / \mathrm{L})$ at extraction well GWEX3, November 2004 to November 2010. 


\section{Carbon Tetrachloride Concentrations at Extraction Well GWEX4}

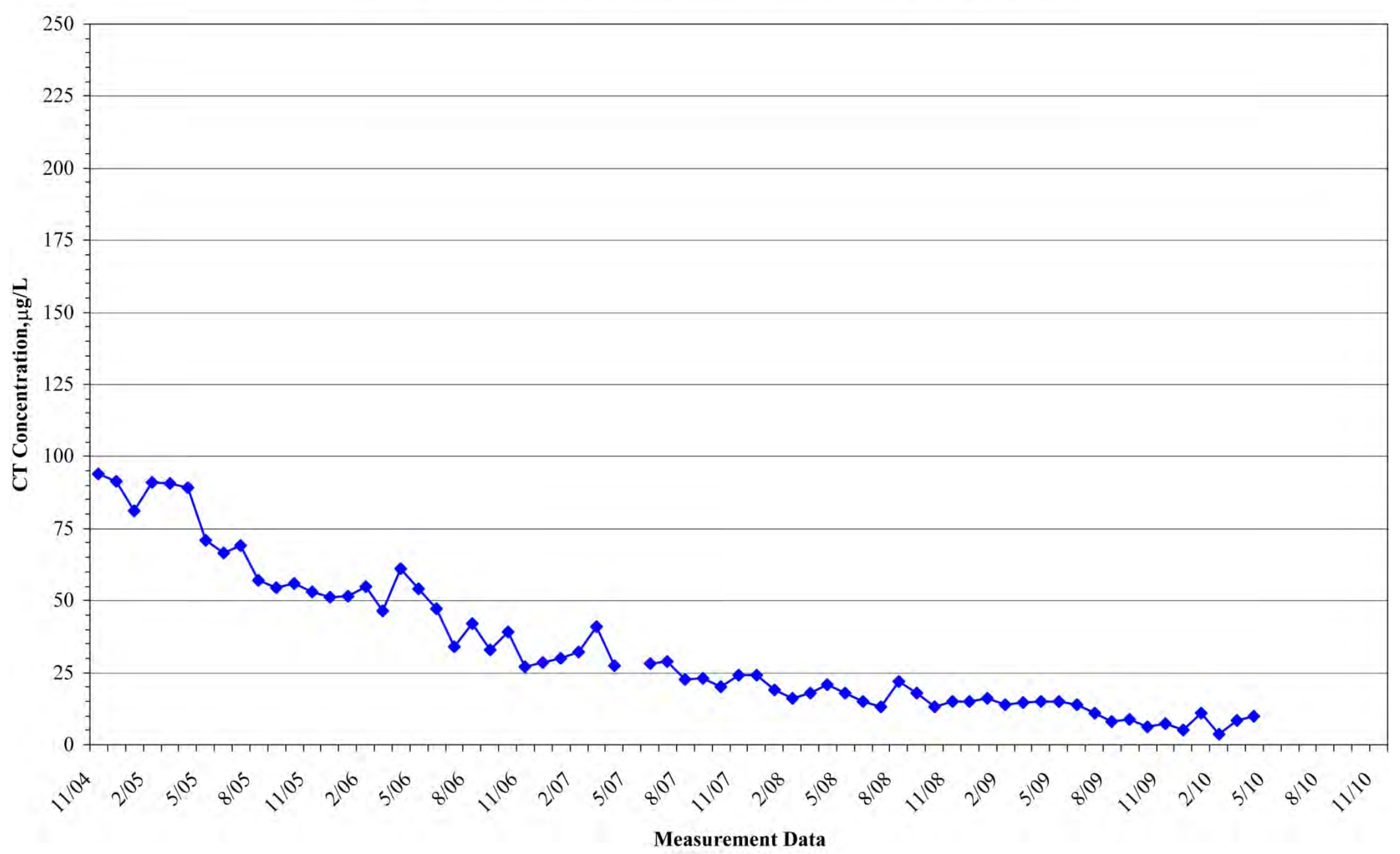

FIGURE 5.5 Carbon tetrachloride concentrations ( $\mu \mathrm{g} / \mathrm{L}$ ) at extraction well GWEX4, November 2004 to November 2010. 


\section{Operation, Maintenance, and System Modifications}

\subsection{Wells GWEX1-GWEX3 and the Spray Irrigation Treatment Units}

No maintenance was required on extraction wells GWEX1-GWEX3 during the current review period.

Maintenance and repairs for the spray irrigation units and the groundwater delivery system were limited to the following activities:

- Periodic field inspection of the units and all operating parameters.

- Seasonal mowing along the gravel access roads and pads at the north and south spray treatment sites.

- Replacement of the pressure sensor (located on one of the irrigation spans) at the south spray treatment site (with a spare gauge obtained previously), to correct intermittent pressure readings that caused GWEX1-GWEX3 and the treatment system to shut down sporadically in July 2010.

\subsection{Well GWEX4 and the Air Stripping Unit}

Maintenance and repairs for well GWEX4 and the air stripping unit included the following:

- Well GWEX4 was returned to service on October 23, 2009, following repairs to the pump and riser pipe that had been completed during the previous review period (Argonne 2010). During the current period - because of increasing sand production, variations in the flow rates from the well, and periodic fouling of the totalizing flow meter used to document the well's performance — periodic cleaning of the flow meter was required in December 2009-April 
2010. In addition, the flow meter was replaced in January 2010 and again in February 2010 to allow the well to continue operating.

- Well GWEX4 was shut down in May 2010 for the 5-yr performance assessment recommended under the approved Monitoring Plan (Argonne 2004) and was not operated for the remainder of the current review period because of the problems noted above. In August 2010 the pump and riser pipe were removed, and a downhole camera survey of the well was conducted. No damage to the casing or screen was readily apparent; however, thick deposits of an unidentified soft material in the deeper parts of the well prevented a detailed inspection of the screen. Alternatives for cleaning and further inspection (or possible repairs) needed to return the well to service were under consideration at the end of the review period.

\subsection{Operating and Maintenance Costs}

Operating and maintenance costs for the aquifer restoration systems at Utica are summarized in Table 6.1. These costs include one-time expenses incurred during the current review period (through November 2010) associated with removal of the pump and inspection of the well casing and screen at GWEX4. Additional costs that might be required to return this well to service will be reported during the next (December 2010-November 2011) review period.

The total operating and maintenance costs for the Utica project during the current review period $(\$ 144,785)$ decreased by approximately 10\% relative to the equivalent costs for December 2008-November $2009(\$ 160,101)$ and were the second lowest annual costs incurred during the initial $6 \mathrm{yr}$ of operation (Table 6.1). The routine operating costs for the current review period were the third lowest to date. Although remediation monitoring costs increased relative to the previous (December 2008-November 2009) review period, this expense was in large measure offset by decreased general management, technical oversight, and logistics support costs during the current review period. Non-routine costs $(\$ 4,645)$ during the current review period were approximately 18\% of those incurred in December 2008-November 2009. 
Table 6.1 also includes one-time costs incurred during the current review period as part of a 5-yr assessment of the groundwater restoration efforts at Utica. These costs are not directly associated with the operation and maintenance of the treatment systems at the site in December 2009-November 2010. The costs for the 5 -yr assessment $(\$ 86,978)$ primarily reflect resampling of the groundwater for VOCs analysis, in vertical profiles at selected locations along the identified plume migration pathway, through use of the Argonne cone penetrometer vehicle (Argonne 2004, 2009b). The results of the 5-yr assessment are being reported separately. 
TABLE 6.1 Summary of operating and maintenance costs for the Utica restoration project.

\begin{tabular}{|c|c|c|c|c|c|c|}
\hline \multirow[b]{2}{*}{ Item } & \multicolumn{6}{|c|}{ Cost $(\$)$} \\
\hline & $\begin{array}{l}\text { Oct 2004- } \\
\text { Nov } 2005\end{array}$ & $\begin{array}{l}\text { Dec } 2005- \\
\text { Nov } 2006\end{array}$ & $\begin{array}{l}\text { Dec 2006- } \\
\text { Nov } 2007\end{array}$ & $\begin{array}{l}\text { Dec } 2007- \\
\text { Nov } 2008\end{array}$ & $\begin{array}{l}\text { Dec 2008- } \\
\text { Nov } 2009\end{array}$ & $\begin{array}{l}\text { Dec 2009- } \\
\text { Nov } 2010\end{array}$ \\
\hline \multicolumn{7}{|l|}{ Routine Costs } \\
\hline General Management & 18,127 & 17,699 & 5,544 & 4,891 & 4,634 & 2,988 \\
\hline Logistics Support & 64,145 & 74,713 & 10,475 & 24,959 & 40,464 & 8,964 \\
\hline Remediation Monitoring & 170,880 & 110,546 & 97,164 & 118,036 & 76,788 & 123,831 \\
\hline Technical Oversight & 17,727 & 5,228 & 13,537 & 8,119 & 12,051 & 4,357 \\
\hline SUBTOTAL & 270,879 & 208,186 & 126,720 & 156,006 & 133,937 & 140,140 \\
\hline \multicolumn{7}{|l|}{ Non-routine Costs } \\
\hline Monitoring Network Establishment & 11,707 & & & & & \\
\hline Radio Control System & & 5,140 & & & & \\
\hline Irrigation Span Repairs & & 57,591 & & & & \\
\hline Valve Actuator Replacement & & & 5,071 & & & \\
\hline Repair of Spray Pad Control Panels, & & & & & & \\
\hline Replacement of Pressure Sensors & & & 2,265 & & 9,628 & \\
\hline Redress Spray Pads and Entry Roads & & & & & 2,968 & \\
\hline Wetlands Survey and Staff Gauge Construction & & & & & 6,845 & \\
\hline GWEX1 Repairs & & & & 12,075 & & \\
\hline GWEX4 Repairs & & & & & 6,723 & 4,645 \\
\hline SUBTOTAL & 11,707 & 62,731 & 7,336 & 12,075 & 26,164 & 4,645 \\
\hline Five-Year Plume Redefinition Sampling ${ }^{a}$ & & & & & & 86,978 \\
\hline TOTAL (routine and non-routine costs) & 282,586 & 270,916 & 134,056 & 168,081 & 160,101 & 144,785 \\
\hline
\end{tabular}

a Costs incurred during the December 2009-November 2010 review period, but not directly associated with the operation or maintenance of the groundwater restoration systems. 


\section{Summary}

Historical performance data and costs for the first $6 \mathrm{yr}$ of operation of the Utica remedial systems are summarized in Tables 7.1 and 7.2.

A combined total of approximately 83 million gallons of contaminated groundwater was extracted and treated during the operation of the aquifer restoration systems at Utica from December 1, 2009, to November 30, 2010. Approximately 86\% of the total volume treated (71.9 million gallons; 222 acre-feet) was used to supplement the natural water entering the North Lake Basin Wildlife Management Area. Discharge of treated groundwater to the wetlands was not possible during four months of the current review period, because of (1) inclement winter weather conditions (January-March 2010) and (2) a temporary shutdown of the extraction wells in May 2010 to facilitate groundwater sampling from the Utica aquifer under ambient (nonpumping) flow conditions for the 5-yr review of system performance.

Groundwater modeling studies performed by Argonne during the development of the aquifer restoration approach for Utica (Argonne 2000) indicated that, on average, the extraction of approximately 97 million gallons of groundwater per year would be required to maintain hydraulic control of the groundwater plume and achieve cleanup of the aquifer in an estimated 10-15 yr. The actual groundwater produced during the December 2009-November 2010 review period represents approximately $86 \%$ of this average annual goal. The highest annual production to date (approximately 119 million gallons; 123\% of the annual target) was achieved in the December 2006-November 2007 monitoring period. The cumulative volume of groundwater extracted and treated by the Utica systems since the aquifer restoration efforts began (Table 7.2) now represents $88 \%$ of the theoretical cumulative target for the 6-yr period November 2004November 2010 (down only slightly from 89\% for the 5-yr period November 2004-November 2009; Argonne 2010).

The original modeling studies (Argonne 2000) suggested that the natural groundwater flow and the contaminant migration rates at this site are sufficiently low to accommodate periodic fluctuations in the volume of groundwater extracted annually, as long as the target average extraction rate is generally maintained. The slightly low groundwater recoveries 
observed during the current (December 2009-November 2010) and previous (December 2007November 2008 and December 2008-November 2009) review periods therefore do not represent an immediate concern. The observed trends in carbon tetrachloride concentrations documented at wells GWEX1-GWEX4 (Section 5.4; Figures 5.2-5.5) indicate that the combined extraction well system is continuing to restrict downgradient migration of contamination within the Utica aquifer. Continued monitoring after well GWEX4 is restarted in the upcoming review period will reveal the effect of the extended shutdown beginning in May 2010 and will indicate whether greater concern about the extraction rate is warranted.

Sampling and analysis of the effluent water from the air stripping and spray irrigation treatment units indicated that during the December 2009-November 2010 review period these systems functioned at a minimum efficiency of $94 \%$ (on the basis of data for individual samples from the spray treatment units). Efficiencies are approximately 99\% for the spray treatment units (calculated on the basis of the average concentration delivered to the wetlands during the review period) and $>99 \%$ for the outfall from the air stripping unit. Carbon tetrachloride concentrations in all discharges of treated water at the site were below the permitted maximum target $(44.2 \mu \mathrm{g} / \mathrm{L})$ by roughly an order of magnitude.

Calculations based on the volumes and measured carbon tetrachloride concentrations of the groundwater extracted and treated during the review period indicated that a total of approximately $8.7 \mathrm{~kg}$ (1.5 gal) of carbon tetrachloride was removed from the Utica aquifer during the December 2009-November 2010 review period. No decrease in the volumetric throughput (when operating) or contaminant removal efficiency of the groundwater treatment systems was observed during the current period (Table 7.1). Table 7.2 shows that a total of approximately $108.3 \mathrm{~kg}$ (18.7 gal) of carbon tetrachloride has been removed from the Utica aquifer during the first $6 \mathrm{yr}$ (November 2004 to November 2010) of operation of the Utica treatment systems.

The costs incurred by Argonne for operating and maintenance of the aquifer restoration effort at Utica during the December 2009-November 2010 review period were approximately $\$ 144,785$, reflecting an approximate $9.6 \%$ decrease in total costs but an approximate 5\% increase in routine costs relative to the previous (December 2008-November 2009) review period. 
Expected additional costs associated with the repairs initiated at well GWEX4 during the current review period will be included in the next (December 2010-November 2011) annual report. 


\begin{tabular}{|c|c|c|c|c|c|c|}
\hline & \multicolumn{6}{|c|}{ Review Period } \\
\hline & $\begin{array}{l}\text { Oct 2004- } \\
\text { Nov } 2005\end{array}$ & $\begin{array}{l}\text { Dec 2005- } \\
\text { Nov } 2006\end{array}$ & $\begin{array}{l}\text { Dec 2006- } \\
\text { Nov } 2007\end{array}$ & $\begin{array}{l}\text { Dec } 2007- \\
\text { Nov } 2008\end{array}$ & $\begin{array}{l}\text { Dec } 2008- \\
\text { Nov } 2009\end{array}$ & $\begin{array}{l}\text { Dec 2009- } \\
\text { Nov } 2010\end{array}$ \\
\hline Groundwater Produced (gal) & $66,364,652$ & $113,949,510$ & $119,274,680$ & $55,228,674$ & $76,693,459$ & $83,271,154$ \\
\hline Groundwater Produced (\% of annual goal) & 68 & 117 & 123 & 57 & 79 & 86 \\
\hline Groundwater DIscharged to Wetlands (gal) & $34,611,960$ & $84,365,500$ & $90,954,300$ & $25,675,200$ & $50,633,300$ & $71,898,100$ \\
\hline \multicolumn{7}{|l|}{ Carbon Tetrachloride in Combined Untreated Groundwater from } \\
\hline GWEX1-GWEX3 ( $\mu \mathrm{g} / \mathrm{L})$ & $100-122$ & 71-139 & $48-90$ & $43-89$ & $30-65$ & $22-53$ \\
\hline Carbon Tetrachloride in Treated Spray Discharge ${ }^{a}$ (range of values, $\mu \mathrm{g} / \mathrm{L}$ ) & $N D^{b}-7.2$ & ND-6.9 & ND-3.7 & ND-4.0 & ND-1.9 & ND-1.6 \\
\hline Carbon Tetrachloride in Treated Spray Discharge ${ }^{\mathrm{a}}$ (average, $\mu \mathrm{g} / \mathrm{L}$ ) & 1.45 & 0.91 & 0.61 & 1.13 & 0.28 & 0.17 \\
\hline Carbon Tetrachloride in Untreated Groundwater at GWEX4 ( $\mu \mathrm{g} / \mathrm{L})$ & $53-95$ & $26-70$ & $20-43$ & $13-24$ & $6.1-16$ & $3.5-11$ \\
\hline Carbon Tetrachloride in Treated Air Stripper Effluent ${ }^{\mathrm{a}}(\mu \mathrm{g} / \mathrm{L})$ & ND & ND & ND & ND & ND & ND \\
\hline Carbon Tetrachloride Removed (kg, gal) & $23,3.8$ & $34,5.6$ & $25,4.1$ & $8,1.3$ & $9.3,1.5$ & $8.74,1.4$ \\
\hline \multicolumn{7}{|l|}{ Minimum Carbon Tetrachloride Removal Efficiency for Spray Treatment (\%) } \\
\hline Based on Individual Samples & $>94$ & $>93$ & $>95$ & $>92$ & $>94$ & $>94$ \\
\hline Based on Averages & $\sim 99$ & $\sim 99$ & $\sim 98$ & $\sim 98$ & $\sim 99$ & $\sim 99$ \\
\hline Carbon Tetrachloride Removal Efficiency for Air Stripper (\%) & $>99$ & $>99$ & $>99$ & $>99$ & $>99$ & $>99$ \\
\hline pH of Treated Spray Discharge ${ }^{\mathrm{c}}$ & 7.01-8.18 & 7.10-8.32 & 7.09-8.36 & $7.88-8.51$ & 7.48-8.43 & $7.40-8.73$ \\
\hline $\mathrm{pH}$ of Treated Air Stripper Effluent ${ }^{\mathrm{c}}$ & $7.01-8.35$ & $7.50-8.58$ & $7.79-8.33$ & $7.71-8.41$ & $6.73-8.45$ & $7.98-8.36$ \\
\hline \multicolumn{7}{|l|}{ Costs $(\$)$} \\
\hline Routine & 270,879 & 208,186 & 126,720 & 156,006 & 133,937 & 140,140 \\
\hline Non-routine & 11,707 & 62,731 & 7,336 & 12,075 & 26,164 & 4,645 \\
\hline TOTAL & 282,586 & 270,916 & 134,056 & 168,081 & 160,101 & 144,785 \\
\hline
\end{tabular}

a Compliance level, $44.2 \mu \mathrm{g} / \mathrm{L}$.

b ND, not detected at a method detection limit of $0.1 \mu \mathrm{g} / \mathrm{L}$.

c Compliance level, 6.5-9.0. 
TABLE 7.2 Results of the groundwater extraction and treatment efforts at Utica, November 2004 to November 2010.

\begin{tabular}{|c|c|c|c|c|c|}
\hline \multirow[b]{2}{*}{$\begin{array}{c}\text { Period } \\
\text { of } \\
\text { Operation }\end{array}$} & \multicolumn{2}{|c|}{ GWEX1- GWEX3 } & \multicolumn{2}{|c|}{ GWEX4 } & \multirow[b]{2}{*}{$\begin{array}{c}\text { Groundwate } \\
\text { Produced } \\
\text { ( } \% \text { of } \\
\text { annual goal) }\end{array}$} \\
\hline & $\begin{array}{l}\text { Production } \\
\text { (gal) }\end{array}$ & $\begin{array}{c}\text { Carbon } \\
\text { Tetrachloride } \\
\text { Removed } \\
(\mathrm{kg})\end{array}$ & $\begin{array}{l}\text { Production } \\
\text { (gal) }\end{array}$ & $\begin{array}{c}\text { Carbon } \\
\text { Tetrachloride } \\
\text { Removed } \\
(\mathrm{kg})\end{array}$ & \\
\hline 2004-2005 & $34,611,960$ & 14.2 & $31,752,692$ & 9.0 & 68 \\
\hline 2005-2006 & $84,365,500$ & 29.2 & $29,584,010$ & 5.0 & 117 \\
\hline 2006-2007 & $90,954,300$ & 21.8 & $28,320,380$ & 3.0 & 123 \\
\hline 2007-2008 & $25,675,200$ & 6.0 & $29,553,474$ & 2.0 & 57 \\
\hline 2008-2009 & $50,633,300$ & 8.0 & $26,060,159$ & 1.3 & 79 \\
\hline $2009-2010$ & $71,898,100$ & 8.4 & $11,373,054$ & 0.4 & 86 \\
\hline Totals & $358,138,360$ & 87.6 & $156,643,769$ & 20.7 & $88^{a}$ \\
\hline
\end{tabular}

a Average production. 


\section{References}

Argonne, 2000, Final Report: Stage I Investigations of the Agricultural/Environmental Enhancement Pilot Program, Utica, Nebraska, prepared for the Commodity Credit Corporation, U.S. Department of Agriculture, by Argonne National Laboratory, Argonne, Illinois, January.

Argonne, 2003, Update on Groundwater Sampling Results for Utica, Nebraska, and Pumping Alternatives for the Utica Aquifer/Wetlands Restoration Pilot Program, ANL/ER/AGEM/CHRON-484, prepared for the Commodity Credit Corporation, U.S. Department of Agriculture, by Argonne National Laboratory, Argonne, Illinois, April 9.

Argonne, 2004, Final Monitoring Plan for the Utica Aquifer-North Lake Basin Restoration Project at Utica, Nebraska, ANL/ER/TR-04/006, prepared for the Commodity Credit Corporation, U.S. Department of Agriculture, by Argonne National Laboratory, Argonne, Illinois, November.

Argonne, 2005, Summary of First-Year Operations and Performance of the Utica Aquifer and North Lake Basin Wetlands Restoration Project in October 2004-November 2005, ANL/EVS/AGEM/TR-05-06, prepared for the Commodity Credit Corporation, U.S. Department of Agriculture, by Argonne National Laboratory, Argonne, Illinois, December.

Argonne, 2006, Summary of Operations and Performance of the Utica Aquifer and North Lake Basin Wetlands Restoration Project in December 2005-November 2006, ANL/EVS/AGEM/TR06-11, prepared for the Commodity Credit Corporation, U.S. Department of Agriculture, by Argonne National Laboratory, Argonne, Illinois, December.

Argonne, 2008, Summary of Operations and Performance of the Utica Aquifer and North Lake Basin Wetlands Restoration Project in December 2006-November 2007, ANL/EVS/AGEM/TR08-05, prepared for the Commodity Credit Corporation, U.S. Department of Agriculture, by Argonne National Laboratory, Argonne, Illinois, February. 
Argonne, 2009a, Summary of Operations and Performance of the Utica Aquifer and North Lake Basin Wetlands Restoration Project in December 2007-November 2008, ANL/EVS/AGEM/TR09-02, prepared for the Commodity Credit Corporation, U.S. Department of Agriculture, by Argonne National Laboratory, Argonne, Illinois, January.

Argonne, 2009b, Update on the Aquifer/Wetlands Restoration Project at Utica, Nebraska, with Recommendations for Remapping of the Carbon Tetrachloride Contamination in Groundwater, ANL/EVS/AGEM/TR-09-10, prepared for the Commodity Credit Corporation, U.S. Department of Agriculture, by Argonne National Laboratory, Argonne, Illinois, October.

Argonne, 2010, Summary of Operations and Performance of the Utica Aquifer and North Lake Basin Wetlands Restoration Project in December 2008-November 2009, ANL/EVS/AGEM/TR10-01, prepared for the Commodity Credit Corporation, U.S. Department of Agriculture, by Argonne National Laboratory, Argonne, Illinois, February. 
Argonne

\section{Environmental Science Division}

Argonne National Laboratory

9700 South Cass Avenue, Bldg. 203

Argonne, IL 60439-4843

www.anl.gov 